\title{
Perceived Conditions of Interstate out Migrated Rural Youth of Assam for Adopt Agricultural Activities
}

\author{
T.V. Kumar* and U. Barman \\ Department of Extension Education, Assam Agricultural University, Jorhat-13, Assam, India \\ *Corresponding author
}

\section{A B S T R A C T}

\begin{tabular}{|l|}
\hline Ke y w o r d s \\
$\begin{array}{l}\text { Interstate out migration, } \\
\text { Unorganized sector, } \\
\text { Snow ball technique, } \\
\text { Nonfarm activities, Off } \\
\text { farm activities }\end{array}$ \\
\hline Article Info \\
\hline $\begin{array}{l}\text { Accepted: } \\
\text { 20 February } 2018 \\
\text { Available Online: } \\
\text { 10 March } 2018\end{array}$ \\
\hline
\end{tabular}

The study on causes and perceived conditions of interstate out migration of rural youths of Assam was conducted with 150 respondents. The present study was conducted at Hyderabad. The respondents were rural youths of Assam migrated to Hyderabad and worked in unorganized sector. The Snow ball technique was applied to select the respondents. Majorities $(88.67 \%)$ of the respondents wanted to leave their present job and was ready to return back to their villages. If the respondents will return back, the majority (39.85\%) of them preferred non-farm activities, 21.80 per cent of the respondents interested on off farm activities, 21.06 per cent $(21.06 \%)$ of the respondents would adopt farming and 17.29 per cent $(17.29 \%)$ of the respondents would start their own business at their villages.

\section{Introduction}

According to 2011 census the population of Assam was 31.16 million out of which $2,607,034$ numbers of people living in rural areas, and 43,98,542 numbers of people living in urban areas.

The youth who are living in rural areas mostly depends on agriculture. However, presently, a trend is observed that rural youths are now reluctant for farming activities and looking for alternate livelihood sources. Because of that they are moving out from rural to urban areas, mainly for non-farm livelihood activities. This also leads to large scale interstate out migration of rural youth from Assam (Population Totals Assam, 2011). FAO (2008) reported that rural out migration tends to exert a downward pressure on agricultural labour per capita.

Many literatures reported that movement of migrants away from rural areas, decreased labour available for farm work (Adebayo and Ajayi, 2001; Angba, 2003; Katz, 2003; McCarthy et al., 2006 and Parganiha et al., 2009).

It ultimately negatively impacted agricultural production. It was indicated that out migration and remittances undermine traditional 
agriculture. Ofuoku and Chukwuji (2012) revealed that migration impacts negatively on plantation agriculture.

Sainath (2013) mentioned that India is losing more than 2,000 farmers every single day and that since 1991; the overall number of farmers has dropped by 15 million. Large-scale migration of rural youth, by withdrawing themselves from farming, to urban areas for non-farm work has caused concern among the country's agricultural policy makers.

If this trend is not checked, is likely to affect agricultural activities in the future. The present study has been conducted with an objective to know the perceived conditions under which out migrant will return back to their villages and adopt agricultural based livelihood activities.

Present study was carried out with following objective.

To determine the perceived conditions under which out migrant will return back to their villages for agricultural based livelihood activities.

\section{Materials and Methods}

The Research design of the present study was "exploratory study". The present study was conducted in Hyderabad city of Telangana state. The state of Telangana comprises of 10 districts among those districts Hyderabad city was purposively selected for the present study. A multi stage sampling design with the snow ball technique was followed in the present study, and total 150 respondents were selected with the snow ball technique. The collected data were coded, tabulated and analyzed in accordance with the objectives of the study utilizing various appropriate statistical procedures like calculating frequency, percentage, mean and standard deviation.

\section{Results and Discussion}

Perceived conditions under which out migrant will return back to their villages

\section{Interest to return back to their villages}

The data in the table 1 shows that the majority $(88.67 \%)$ of the respondents would leave their present job and ready to return back if better opportunities are found. Only 11.33 per cent $(11.33 \%)$ of the respondents expressed that they will continue the job at destination and will not return back permanently to their villages.

The data in the table 1 shows that the respondents who would interest to return back, the majority (39.85\%) of them preferred nonfarm activities, 21.80 per cent of the respondents interested on off farm activities, 21.06 per cent of the respondents would adopt farming and 17.29 per cent of the respondents would start their own business.

\section{The conditions needed to adopt agricultural based activities}

From the data table 2 it was found that all 28 respondents $(100.00 \%)$ needed the conditions of availability of subsidized fertilizers, pesticides and quality seeds. About 96.42 per cent $(96.42 \%)$ of the respondents needed implementation of crop insurance scheme in flood affected areas, 92.85 per cent $(92.85 \%)$ of the respondents needed the condition of availability of crop loans, 85.71 per cent $(85.71 \%)$ of the respondents needed irrigation facilities, 82.14 per cent $(82.14 \%)$ of the respondents needed training on remunerative crops, transportation and marketing facilities for crop output and 75.00 per cent $(75.00 \%)$ of the respondents needed extension officer's support and guidelines. These are some common problems faced by the farmers of Assam. 
Table.1 Interest to return back to their villages

\begin{tabular}{|c|c|c|c|c|}
\hline Sl. No. & Questions & Response category & Frequency & Percentage \\
\hline \multirow[t]{3}{*}{1} & \multirow{2}{*}{$\begin{array}{l}\text { If given a chance or good } \\
\text { opportunity come, will you } \\
\text { return back to your village }\end{array}$} & $\begin{array}{l}\text { I will continue the job at } \\
\text { destination }\end{array}$ & 17 & 11.33 \\
\hline & & $\begin{array}{l}\text { I will leave the job and } \\
\text { return back to my village }\end{array}$ & 133 & 88.67 \\
\hline & Total & & 150 & 100 \\
\hline Sl. No. & Questions & Response category & Frequency & Percentage \\
\hline \multirow[t]{5}{*}{1} & \multirow{4}{*}{$\begin{array}{l}\text { If you return back to your place } \\
\text { what work will you preferred }\end{array}$} & Farming & 28 & 21.06 \\
\hline & & Farming and Off farm & 29 & 21.80 \\
\hline & & Non farm & 53 & 39.85 \\
\hline & & Own business & 23 & 17.29 \\
\hline & Sub Total & & 133 & 100 \\
\hline
\end{tabular}

Table. 2 The conditions needed to adopt agricultural based activities

\begin{tabular}{|c|l|c|c|}
\hline SI. No. & Conditions & Frequency & Percentage \\
\hline $\mathbf{1}$ & $\begin{array}{l}\text { Availability of subsidized inputs like fertilizers and pesticides in } \\
\text { time }\end{array}$ & 28 & 100 \\
\hline $\mathbf{2}$ & Availability of quality seeds & 28 & 100 \\
\hline $\mathbf{3}$ & Need training on remunerative crops & 23 & 82.14 \\
\hline $\mathbf{4}$ & Extension officer support and guidelines & 21 & 75.00 \\
\hline $\mathbf{5}$ & Availability of irrigation facilities & 24 & 85.71 \\
\hline $\mathbf{6}$ & Availability of crop loans & 26 & 92.85 \\
\hline $\mathbf{7}$ & Transportation and Marketing facilities for crop output & 23 & 82.14 \\
\hline $\mathbf{8}$ & Implementation of crop insurance scheme in flood affected areas & 27 & 96.42 \\
\hline
\end{tabular}

Table.3 The conditions needed to adopt off farm activities

\begin{tabular}{|c|c|c|c|}
\hline Sl. No. & Conditions & Frequency & Percentage \\
\hline 1 & Need higher wages to agricultural labour & 29 & 100 \\
\hline 2 & Year round guaranteed work in and around the village. & 29 & 100 \\
\hline 3 & $\begin{array}{l}\text { Implementation of the Government schemes for the benefits } \\
\text { of agricultural labours. }\end{array}$ & 24 & 82.75 \\
\hline 4 & $\begin{array}{l}\text { Facilities of credit to start enterprises like poultry, piggery } \\
\text { etc. in their small landholdings }\end{array}$ & 27 & 93.10 \\
\hline
\end{tabular}

Table.4 The conditions needed by respondents to adopt non-farm activities

\begin{tabular}{|c|l|c|c|}
\hline Sl. No. & \multicolumn{1}{|c|}{ Conditions } & Frequency & Percentage \\
\hline $\mathbf{1}$ & Getting employment throughout the year & 53 & 100 \\
\hline $\mathbf{2}$ & Giving better wages to non farm workers & 51 & 96.22 \\
\hline $\mathbf{3}$ & Need credit facilities to start own business if wanted & 53 & 100 \\
\hline $\mathbf{4}$ & Need support of government schemes for non farm workers & 53 & 100 \\
\hline $\mathbf{5}$ & Provision of training on entrepreneurship development & 49 & 92.45 \\
\hline
\end{tabular}


Once these will solve, people may show their interest to farming again. This finding is in conformity with the results of Tacoli (2002), Zachariah and Rajan (2009), Goldring (2003).

The conditions needed to adopt off farm activities

From the data table 3 it was found that all the 29 respondents $(100.00 \%)$ who preferred an off farm activity needed the conditions of high wages to agricultural labour, year round work in and around the villages, 93.10 per cent $(93.10 \%)$ of the respondents needed facility of credit to start poultry, piggery farms etc. in their small landholdings. About 82.75 per cent $(82.75 \%)$ of the respondents needed the condition of implementation of the Government schemes for the benefits of agricultural labours.

\section{The conditions needed by respondents to adopt non-farm activities}

From the data table 4 it was found that all the 53 respondents (100.00\%) who preferred nonfarm activities needed the conditions to provide employment throughout the year, needed credit facilities to start own business, needed the support of the government schemes. About 96.22 per cent of the respondents needed better wages to non-farm workers, and 92.45 per cent of the respondents needed the condition to conduct training for entrepreneurship development.

It can be concluded that the respondents were not interested in farming and other off farm activities. The reason was that majority of the respondents have less land holding and the farming is not economically viable. So they were interested in non-farm activities.

This finding is in conformity with the results of Tacoli (2002), Zachariah and Rajan (2009) and Goldring (2003).
Majority of the respondents would leave their present job and ready to return back if better opportunities are found. If the migrants return back to their villages, majority of the respondents adopt non-farm activities. Government should help the rural youth for establishing their own enterprises. Government should also develop the agro eco-tourism sector in the state because the sector has a potentiality to create more employment. It is necessary to provide training, support and guidance for all those occupations which any skill based like carpenters, cobblers, welders, blacksmiths, masons, nurses, tailors, weavers etc. Through Skill India programme it may be done.

\section{References}

Adebayo, K. and Ajayi (2001). Factors determining the practice of crop livestock integration in the derived savanna and rainforest zones of Nigeria. ASSET Series A. 1(1): 91-100.

Angba, A.O. (2003). Effect of rural-urban migration of youths on agricultural labour supply in Umuahia north local government area of Abia state, Nigeria. Journal of Advanced Scientific Research 3(2): 77-83.

Food and Agriculture Organization (FAO) of the United Nations (2008). Agriculture and Rural Development: A FAO prospective. www.fao.org

Food and Agriculture Organization. Retrieved 16 march 2015 from http://www. cabidirect.org.

Goldring, L. (2003). Re-thinking remittances: Social and political dimensions of individual and collective remittances' CERLAC Working Paper Series, February 2003, York University.

Katz, E. (2003). The changing role of women in the rural economics of Latin America. In Davis, B. (Ed), Current and Emerging Issues for Economic Analysis 
and Policy Research. 1: 31-66. Latin America and the Caribbean.

McCarthy Carletto, N.; Davis, G. and Maltsglou, I. (2006). Assessing the impact of massive out-migration on agriculture. ESA Working Paper, No. 06-14, FAQ, Rome. Retrieved from 12 march 2015 from http://www.iosr joumals.org.

Ofuoku and Chukwuji (2012). The impact of rural-urban migration on plantation agriculture in Nigeria Delta Region, Nigeria. Journal of Rural Social Sciences 27(1): 137-51.

Pargaih, O.P.; Sharma, M.L.; Praye, P.M. and Soni, V.K. (2009). Migration effect of agricultural labourers on agricultural activities. Indian Research Journal of Extension Education 9(3): 95-98.

Population totals Assam, (2011). Paper 2, volume 1, data on rural and urban population.

Sainath, P. (2013). Over 2,000 Fewer Farmers Every day. The Hindu. Web. 6 Dec.
2013. Retrieved 23 July 2015 from http://www.thehindu.com/opinion/colu mns/sainath/over-2000-fewer-farmersevery-day/article 4674190.ece.

Tacoli, C. and D. Satterthwaite (2002). The urban part of rural development: the role of small and intermediate urban centers in their regional and local economies, including rural development and poverty reduction. International Institute for Environment and Development.

The Hindu. Web. 6 Dec. 2013. Retrieved 23 July 2015 from http://www.thehindu. com/opinion/columns/sainath/over-2000 -fewer-farmers-every-day/article 46741 90.ece.

Zachariah, K.C. and Rajan, I.S. (2009). Impact of the global recession on migration and remittances in Kerala: New evidences from the return migration survey (RMS) working paper 432.

\section{How to cite this article:}

Kumar, T.V. and Barman, U. 2018. Perceived Conditions of Interstate out Migrated Rural Youth of Assam for Adopt Agricultural Activities. Int.J.Curr.Microbiol.App.Sci. 7(03): 22732277. doi: https://doi.org/10.20546/ijcmas.2018.703.267 